\title{
The More Summer Milk project - a participant's view
}

ANDREW SINGER

Dairy farmer, Pokeno

We purchased this property at Pokeno as a dry stock unit and converted it to dairying. Production in the first season (1989/90) was $16500 \mathrm{~kg}$ milkfat $(29500 \mathrm{~kg}$ milksolids).

Our farm is 60 effective ha (plus a large undeveloped area of the Mangatawhiri swamp), with a 20 ha runoff. The farm is 30 ha of stumpy peat soils, stopbanked but floodable from upstream ponding, and 30 ha of rolling Hamilton clay soils (75\% mowable).

\section{Development}

A pumping system was installed in 1994.

Over $50 \%$ of the flats has been regrassed in a programme involving stumping or stump chipping, consolidation and regrassing.

Summer crops have been grown as part of the consolidation phase of development. These have included green feed maize, sorghum, Pasja, and turnips.

Early regrassing was done with Yatsyn, Pitau, Pawera mixes. We are currently using Embassy, Aran/ Kopu, and Colenso.

A capital fertiliser programme has raised soil test data to respectable levels.

\section{Management}

Franklin District is commonly accepted as a dry summer area, and we have tried to manage the farm to fill the summer gap with crops that fit in with development, with silage when available, and with bought in feeds such as squash.

\section{The More Summer Milk trial}

When the More Summer Milk project was looking for farms for the 1994/95 season we decided to offer our property. We saw it as a chance to find out for ourselves, and from other farms in the project, how best to improve the summer production drop.

The trial involves running a split herd operation with a control herd and a trial herd. The aim is to supplement the trial herd with $4 \mathrm{~kg}$ DM per cow for 100 days over the summer. We have to finish the season with the same available feed on both farmlets and with both herds in the same condition score.

We have stayed in the trial for three years.
For the first two seasons we grew Barkant turnips. The trial required $10 \%$ of the trial farmlet planted by 1 November. We have grown turnips before, but in Year 1 the crop was not a success. The crop was badly infested with weeds, which had not been our normal experience. Turnip yields were between 5-6 t DM/ha at 100 days' growth. There was a small production response while the crop lasted, but the herd lost production before and after feeding, while the crop land was out of grass. The second crop in 1995/96 was better, at $10 \mathrm{t} \mathrm{DM/ha,} \mathrm{but}$ the extra production from the turnips still did not make up for the losses while the crop grew, and while the new grass was established.

Year 3 we trialled nitrogen at $30 \mathrm{~kg} / \mathrm{ha}$ in November with a 40-day summer grazing rotation. We did not effectively use all the available feed in NovemberDecember, but the extra production from the trial herd was still profitable.

\section{Summary of trial}

It has meant more work for us. Managing two herds, recording inputs, monitoring pastures, all take more time.

However, other farmers accept the results as "real". We have had good turnouts of 80 to over 100 people at the field-days over the three years, and I have been regularly asked how the trial was going, by people I didn't know, at all sorts of places.

Scientists get out to see that it's not a perfect world off the research station, and that farmers have many limitations they may not normally have to cope with. This includes such things as the ability to collect good data with limited people available, and problems of getting things done at the right time, whether this is fitting cultivation work into the rest of the farm work and the weather, or getting the silage contractor onto the farm when I want him.

Farmers involved in the trial have a lot more data available, such as pasture growth rates and average pasture cover data, botanical composition of pastures, and analyses of supplements.

There have been benefits from meeting other farmers involved in the trial. They may be running a different treatment, but the chance to discuss results and to understand why and how the results come out the way they do is very valuable. 
Table 1 Monthly production data for four seasons.

\begin{tabular}{lcccc}
\hline & $1993 / 94$ & $1994 / 95$ & $1995 / 96$ & $1996 / 97$ \\
Cow nos & 168 & 166 & 181 & 164 \\
Calving Date & 15 July & 1 July & 25 June & 15 July \\
kg milksolids & & & & \\
\hline July & 425 & 1335 & 2326 & 590 \\
Aug & 4277 & 4771 & 4009 & 3883 \\
Sept & 6679 & 5703 & 4572 & 4960 \\
Oct & 7139 & 6278 & 6332 & 5806 \\
Nov & 7625 & 5772 & 5614 & 5890 \\
Dec & 7135 & 4295 & 5081 & 5604 \\
Jan & 4639 & 2440 & 4629 & 5152 \\
Feb & 2904 & 2536 & 3923 & 3583 \\
Mar & 1713 & 2765 & 2921 & 2909 \\
Apr & & 1550 & 1470 & 1605 \\
Season Total & $\mathbf{4 2 5 3 6}$ & $\mathbf{3 7 4 4 5}$ & $\mathbf{4 0 8 7 7}$ & $\mathbf{3 9 9 8 2}$ \\
to 31 Dec & 35894 & 28154 & 27934 & 26733 \\
1 Jan to end & 6642 & 9291 & 12943 & 13249 \\
\hline
\end{tabular}

Table 2 Farm production data for four seasons.

\begin{tabular}{lcccc}
\hline $\begin{array}{l}\text { Farm area } \\
60 \text { ha }\end{array}$ & $1993 / 94$ & $1994 / 95$ & $1995 / 96$ & $1996 / 97$ \\
\hline Cow nos & 168 & 166 & 181 & 164 \\
Calving date & 15 July & 1 July & 25 June & 15 July \\
kg milksolids & & & & \\
season & 42536 & 37445 & 40877 & 39982 \\
to 31 Dec & 35894 & 28154 & 27934 & 26733 \\
1 Jan to end & 6642 & 9291 & 12943 & 13249 \\
\hline
\end{tabular}

I understand the "control-treatment" approach to research much better after being involved, and being able to see the results for myself.

There has been personal motivation for us.

When we look at the results of the trial on our farm and our annual production figures, our conclusion is that it is going to be much more profitable to get the spring right first, perhaps use some nitrogen to carry some grass or silage into the summer, but not to spend up on bought in feed for the dry period. It is probably better to dry off at this stage. 